\title{
English Tenses and Conventions in Research Report Writing
}

\author{
Wahjuningsih Usadiati, Maida Norahmi \\ English Education Study Program \\ University of Palangka Raya, \\ Palangka Raya, Indonesia \\ wahyu.usadiati@edu.upr.ac.id
}

\begin{abstract}
Appropriate use of English tenses and conventions is a must for students who write their thesis in English. It is imperative whether they are aware of the appropriateness to translate their research activities into a written form that conform to the expectations of scientific and academic community. A survey was conducted to 65 out of a population of 124 students of the English Education Study Program of Universitas Palangka Raya who were writing the draft of their research report. The survey was done to obtain data on the use of English tenses and conventions in the Introduction part of their thesis research report writing. The results showed that the inappropriateness of the use of English tenses and conventions occurred due to the lack of understanding on the appropriate use of the English tenses and conventions in the Introduction Part. They used incorrect tenses in stating the arguments and in quoting previous research results. They did not provide a clear setting to move from the general area toward more specific topic of the research. They could not differentiate report-oriented style from research-oriented style in communicating the information about their research.
\end{abstract}

Keywords-English Tenses and Conventions, Report Writing

\section{INTRODUCTION}

Writing a thesis or research report is a must for undergraduate students of English Education Study Program at Universitas Palangka Raya, Central Kalimantan, Indonesia. Thesis writing is a compulsory requirement to get a predicate of a Sarjana Pendidikan Bahasa Inggris (Bachelor of English Education). Besides, students are also required to write a research report for certain courses along with their academic activities. Regarding the demands of research report writing, the students are expected to have the ability in writing appropriate research report in English. The ability includes using appropriate tenses to state the activities whether they will be done in the future or they have been done in the past; understanding the conventions in report writing structure; and choosing the appropriate writing styles. Due to the different nature of Bahasa Indonesia and English, the students should be able to switch their thinking and mindset of the way of writing the research reports in English. Although there are quite similar research writing conventions, the students are probably missing to set the ground of the research even in the Introduction Part of the report in English.

Writing a research report in English can be potentially problematic for the majority of students of English Education Study Program of Universitas Palangka Raya. The confusion of using appropriate English tenses and conventions were found due to the interferences of students' first language. In English, certain kinds of tenses have to be used for certain occasions and time lapse of activities [1]. Such problem becomes bigger since they just translate all the research activities from their first language into English in which both languages are quite distinctive in syntactical structures and conventions. To avoid misleading understanding, they should be able to think in English rather than thinking in Bahasa Indonesia and then translating it into English. Such problem influences the structure in the research report writing in English.

Tenses play a very important role in English. Tenses are included in language components of structure and determined the time when the action is done by the agent in the sentence [1][2]. In research report writing, tenses indicate the time when the research activities are carried out. It is very essential to use appropriate tenses based on the information delivered to readers in order to avoid confusion of the activities done in the research. In Introduction Part of research report, the dominant employed tenses are simple present tense and present perfect tense to state the background of the research.

Based on the handouts of the University of Melbourne (2012) and the University of North Carolina (2014), in Introduction Part present tense is used to introduce and explain the topic of research to set the research background, and present perfect tense is used to describe and to relate the phenomenon occured in the topic. The understanding of those will determine whether the Introduction Part provides reasonable ground for the readers to read further. The lack of undestanding on this field will lead the students' writing become misleading since the Introduction Part should include some stages to maintain clarity of information for the readers [3]. Moreover, the information can be assumed unclear when it is not presented properly. The combination of these problems reflects the inappropriateness of the Introduction Part of students' report writing that needs to be overcome.

The ability to write up the results of research in the form of thesis is a key to success of university students. This statement has long been put forward by [4] who state that writing up the research results is to report to the scholarly community all what have been done in conducting the research. The Introduction Part of the report, besides using particular tenses, also applies specific rules or conventions to be set up. The mastery of the language convention in English plays an important role. By mastering the language convention, they are able to translate 
their research activities into written form that conform to the expectations of the English-speaking scientific or academic community. The English language conventions involve matching linguistic forms to rhetorical purposes, which means conforming the grammatical structures which are "specific" in terms of scientific writing. Potential grammatical structures to be problems in research writing include misuse of verbs, dictions, articles, prepositions, and particles [5].

Five stages of sequenced information which are typical conventions in the Introduction part in writing a research report $[6][7][8][9]$. The first stage is stating the general statement(s) about the topic of research to provide readers with a setting for the problem to be reported. In the second stage, more specific statements are stated in brief about the aspects of the problem already studied by previous researchers. The need for more investigation is then stated in the third stage; followed by the fourth stage of specifying the purpose or objectives of the study. In the last stage of the Introduction, there are optional statement(s) about the value or justification for carrying out the study.

Using appropriate tenses and standardized conventions in writing an English research report is a must for those who want to convey the information to the readers of research being done. Since the task is writing in English, the writers of the research report follow tenses for certain part of report and conventions to make the infomation be precisely caught by the target audience. In presenting the information, the conventions can interfere the style of writing [10]. He explains that the conventions convey the discourse of information and they should be communal. It is very possible that conventions in writing can emerge as the style of a writer or it can be attached whenever the writers of the research report write another report (or it can be conducted under the requirements of publication). The conventions which give the writers way to avoid the errors occur when writing a research report should be under the writers' consideration. The classic errors that should be avoided when following the conventions are described by [11], such as: unobvious subject or object, excessive prepositonal phrases, judgemental adjectives, and the expression of belief. The need of correct quoting activities can be included in the case of expression of belief and the way of making quotations is under the consideration.

The researchers view that it is important to consider the effects of misusing the English tenses and conventions in the Introduction Part in writing a research report. It is considerable to have the Introduction Part as the writing sample, since it is the first part of a research report and is frequently viewed as the important part to continue to read and to shape the following parts of a research report. If the understanding can be gained in the first part, it will be easier to use appropriate tenses, conventions, and writing styles for writing the following parts or chapters.

The existing research is designed to reveal the reasons why the students have misunderstanding in the use of the above rules. The student's way of thinking and writing will be the main source of data to provide general view of how to write an English research report. Based on the reasons above, the researchers are eager to design and conduct a survey research to map the students' perception in using appropriate English tenses and conventions. Therefore, the objective of the research is to investigate and analyze the students' perception on the use of
English tenses and conventions on the Introduction Part in research report writing.

\section{METHOD}

The research was conducted in a survey research design to picture the students' opinions or perceptions as the main source of data toward the topic under the research. The research approach used was qualitative approach in which the analysis and conclusion were drawn qualitatively and quantatively.

The subjects involved in this research were the students of the English Education Study Program of Universitas Palangka Raya, Central Kalimantan, Indonesia who were taking the course of Scientific Writing and who have submitted their research report drafts. The total research subjects were 65 students out of 124 students. They were mostly students of the sixth semester who have previously taken Structure and Writing courses.

The procedure of data collection done is presented as follows:

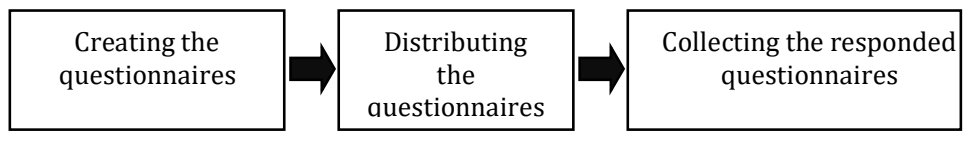

Fig. 1. The Procedures of Data Collection

Sixty-five open-ended questions were distributed to the students who became the research subjects. The questionnaire was constructed based on the theories proposed by [6][7][8][9] the five stages of writing a research report in English, which consisted of 16 statements. In the questionnaire, statements 1 and 2 asked the difficulties in following the 5 stages and language conventions in research report writing. Statements 3, 4 , and 5 pictured the problems in writing research setting (stage 1). The following statement 6 was about the difficulties in writing the more specific concept or topic already studied (stage 2 ). The difficulties in citing or quoting were asked in statements 7, 8, 9. and 10. Statements 11 and 12 asked the difficulties in writing the need for more information (stage 3). Difficulties in writing specific objectives (stage 4) were stated in statements $13,14,15$ and 16 . The last two statements 17 and 18 asked the difficulties in writing research justification and using modal verbs.

The questionnaire was constructed in Bahasa Indonesia to make the students easier to give their responses. Regarding the issue of ethics in research, the questionnaire returned by the students remained no name, as it was also done to avoid bias in the process of analyzing the questionnaires.

The researchers employed the model of qualitative data analysis based on [12] to analyze the data, i.e. the students' responses on the questionnaire. The model of the data analysis procedure of the research is presented as follows:

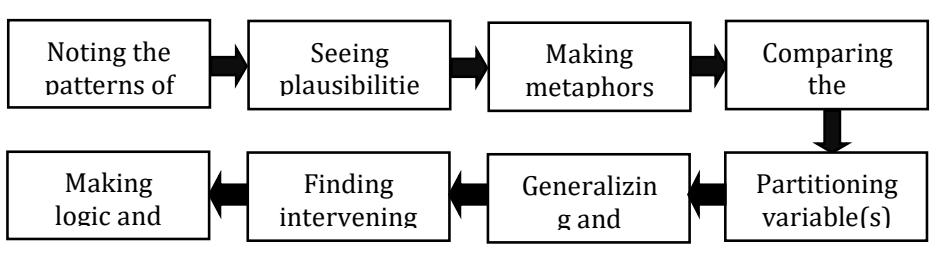

Fig. 2. Data Analysis Procedure 
Firstly, the trends of the students' responses were pictured. Secondly, all of the students' responses on the questionnaires were read to see some plausibilities, then some criteria based on the information obtained from all responses were created and counted to make the comparison and to see variables existing among the responses. After partitioning variables, the generalization of the responses was made. Then, the generalization of data was compared to the existing intervening variables to meet the research conclusion. Firstly, the trends of the students' responses were pictured. Secondly, all of the students' responses on the questionnaires were read to see some plausibilities, then some criteria based on the information obtained from all responses were created and counted to make the comparison and to see variables existing among the responses. After partitioning variables, the generalization of the responses was made. Then, the generalization of data was compared to the existing intervening variables to meet the research conclusion.

\section{RESUlT AND DISCUSSION}

After analyzing and calculating the responses, some information were obtained as the research findings referring to the statements in the questionnaire. They are summarized as follows:

TABLE I. QUESTIONNAIRE ANALYSIS

\begin{tabular}{|c|c|c|c|c|c|c|}
\hline \multirow[b]{2}{*}{ Statement } & \multicolumn{3}{|c|}{ Total Response } & \multicolumn{3}{|c|}{ Percentage } \\
\hline & Yes & $\begin{array}{c}\text { Doub } \\
\text { tful }\end{array}$ & No & Yes & $\begin{array}{c}\text { Do } \\
u b t f \\
u l\end{array}$ & No \\
\hline \multicolumn{7}{|l|}{ Difficult to: } \\
\hline $\begin{array}{l}\text { follow } 5 \text { stages in research } \\
\text { report writing in English }\end{array}$ & 25 & 25 & 15 & 38 & 38 & 24 \\
\hline $\begin{array}{l}\text { follow language convention } \\
\text { in research report writing in } \\
\text { English }\end{array}$ & 35 & 25 & 5 & 54 & 38 & 8 \\
\hline $\begin{array}{l}\text { understand how to write } \\
\text { research setting ( stage } 1 \text { ) }\end{array}$ & 10 & 25 & 30 & 16 & 38 & 46 \\
\hline $\begin{array}{l}\text { relate research setting with } \\
\text { general idea }\end{array}$ & 9 & 31 & 25 & 14 & 48 & 38 \\
\hline $\begin{array}{l}\text { use appropriate tenses in } \\
\text { stage } 1\end{array}$ & 11 & 24 & 30 & 17 & 37 & 46 \\
\hline $\begin{array}{l}\text { write more specific concept } \\
\text { or topic already studied } \\
\text { (stage } 2)\end{array}$ & 22 & 28 & 15 & 34 & 42 & 24 \\
\hline $\begin{array}{l}\text { quote using weak author } \\
\text { prominence }\end{array}$ & 20 & 20 & 25 & 31 & 31 & 38 \\
\hline $\begin{array}{l}\text { quote using information } \\
\text { prominence }\end{array}$ & 20 & 21 & 24 & 31 & 32 & 37 \\
\hline $\begin{array}{l}\text { quote using author } \\
\text { prominence }\end{array}$ & 16 & 25 & 24 & 25 & 38 & 37 \\
\hline $\begin{array}{l}\text { use appropriate tenses in } \\
\text { quoting previous studies }\end{array}$ & 9 & 34 & 22 & 14 & 52 & 34 \\
\hline $\begin{array}{l}\text { relate the need for more } \\
\text { information with the present } \\
\text { study (stage } 3 \text { ) }\end{array}$ & 26 & 20 & 19 & 40 & 31 & 29 \\
\hline $\begin{array}{l}\text { use appropriate tenses in } \\
\text { stage } 3\end{array}$ & 14 & 27 & 24 & 22 & 41 & 37 \\
\hline $\begin{array}{l}\text { relate specific objectives } \\
\text { (stage 4) with research } \\
\text { statement or problem }\end{array}$ & 25 & 15 & 25 & 38 & 24 & 38 \\
\hline $\begin{array}{l}\text { write stage } 4 \text { using statement } \\
\text { sentences }\end{array}$ & 15 & 20 & 30 & 23 & 31 & 46 \\
\hline $\begin{array}{l}\text { write stage } 4 \text { using question } \\
\text { sentences }\end{array}$ & 15 & 25 & 25 & 24 & 38 & 38 \\
\hline
\end{tabular}

\begin{tabular}{|l|l|l|l|l|l|l|}
\hline $\begin{array}{l}\text { write stage 4 using } \\
\text { appropriate tenses }\end{array}$ & 15 & 30 & 20 & 23 & 46 & 31 \\
\hline $\begin{array}{l}\text { write justification (stage 5) of } \\
\text { the importance of the present } \\
\text { study }\end{array}$ & 13 & 26 & 26 & 20 & 40 & 40 \\
\hline $\begin{array}{l}\text { write stage 5 using } \\
\text { appropriate modal verbs }\end{array}$ & 11 & 27 & 27 & 18 & 41 & 41 \\
\hline
\end{tabular}

Based on the results displayed in Table 1, it can be stated that most of the subjects found problems in writing the Introduction Part. The total number of students who answered "Yes" and "Doubtful" was higher than those confidently answered "No" on the difficulties of writing research report in English. Since the total number of "Yes" and "Doubtful" responses was dominant among the answers, it can be concluded that the students mostly failed to write appropriate Introduction Part of a Research report in English. The main problems emerged were the misuse of tenses, unclear background setting, incorrect quoting, and inappropriate way of communicating the information. These findings provide the chances for the researchers to find out the reasons behind their problems. Because of the needs to look for the reasons, the students' responses above need to be patterned.

Further analysis was conducted to capture the patterns as the information of the source of difficulties (problems). Then, the activities of comparing and clustering were aimed at finding the reasons underlining the the subjects' responses. After finishing further analysis of the questionnaires, the researchers wrote down the patterns mostly pictured based on the responses given. Besides, the plausibilities of the responses were at the same time considered. Finally, the patterns were clustered according to the sources of problems in writing the Introduction Part of an English research report. The patterns are noted as in the following figure:

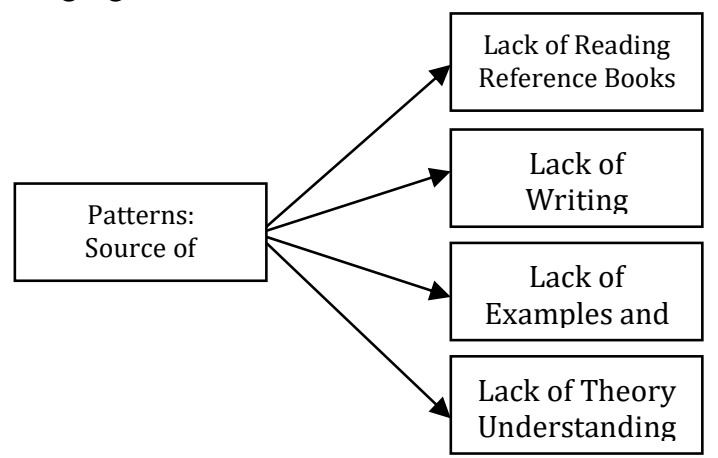

Fig. 3. The Patterns and Clusters of Students' Responses in the Questionnaire

Based on the analysis of total students' answers, the patterns obtained were made on the students' responses in the questionnaire. Those patterns revealed the reasons why most of them found difficulties in writing the Introduction Part. Although some intevening variables might influence the ability to write, the responses showed quite similar answers towards the same statement. The four patterns were categorized as the major clusters, and they were analyzed to cope with all the responses given in the questionnaires. The four were assumed as the underlining causes that influenced the students to answer "Yes" and "Doubtful" and also the problems they faced.

As stated previously, in order to report the research which has been done, mastery of English tenses and convention is a must [4]. Lack of reading the guidelines and the reference books 
was one of the causes that interfered the students not to be successful in writing clear background setting. In the Introduction Part, the students were asked to follow the five stages as suggested in the guidelines by [6][7]. Based on the reasons given, less reading led the students to incorrectly follow the five stages in the Introduction Part. The five stages were clearly described in the guidelines, and the students needed to follow them. Several students who stated not having any difficulties in understanding the five stages said that they carefully followed the guidelines that finally they gained the understanding. Refering to the lack of reading, it was assumed that the students who were unable to construct the background properly did not give themselves more time to read or to check the guidelines or reference books. Besides, the problem of misusing the tenses was also due to the lack of reading. Willingness to do some checks on the appropriate tenses used for certain part can easily determine the tenses to be used.

In regard to the ability of writing clear background setting, the students seemed confused of providing ideas or information needed. This is in line with [3] that to maintain clarity of information for the readers to read, some stages of report writing should be followed. Majority of the students were not used to or not familiar with writing the ideas that clarity of information for the readers was missing. This was due to the fact that writing research report was not their habit. Since writing research report was not the usual activities for them, they seemed confused and doubtful whether what they have written in the background was the required one. Since the ability of good writing is not instant, the students need to have more practices under the advisory of the lecturers. Some of them stated that they have never practiced writing research report. It was quite surprising since they have been in the sixth semester and have got Structure and Writing courses as the basic skills in writing. Considering in what the semester they are, they should have experienced in writing such research reports as they have already finished the assignments or projects given by lecturers on the previous courses. Therefore, having less experience and habit in writing become one of the reasons marking the problem in writing the information on the background setting.

Majority of the students' responses showed having insufficient examples and explanations were one of the causes influencing them to be unable to provide good writing of the Introduction Part, including the background setting and the way of quoting. They stated that the examples and explanations were not adequately given in classroom activities. Hence, they were hard to construct the complete picture of the kind of the Intoduction Part to be written. The gulity feeling that what they were writing was not the required one made the students needed to crosscheck with the examples, that they wanted more examples and explanations to be provided. Relatively similar reasons answered the problem of misused tenses and conventions. This is line with [5] that potential problems in research writing occur due to misuse of verbs (modals) and diction. The confusion of determining the appropriate tenses to be used in certain parts or information could be minimized by providing more examples so the students could refer to them while writing. Providing more examples and giving more explanation (or more exercises on tenses) is assumed to be able to help the students write the appropriate tenses and conventions in the Introduction Part.
The theories of tenses and conventions certainly influenced the students' basic knowledge of writing research report in English. The lack of those theories led the students to the confusion of determining the tenses to be used in the Introduction Part. The effect then emerged as the students could not understand how to deliver the information in the appropriate grammar format to approach the readers. The theories of tenses and convention were not directly taught in Scientific Writing course; they should have been acquired in the previous courses. As also stated by [2], such knowledge of the theories became fundamental since the students' reasons of failing in choosing the appropriate tenses and conventions mostly related to the understanding of the theories. Students should be able to switch their mindset to think directly in English rather than thinking in Bahasa Indonesia and transferring it into English. Some other students felt it was easy to determine the appropriate tenses and convention due to their previous adequate experiences and fine understanding of grammar. It means the students who mostly felt difficult to do the same did not experience and stucturize the knowledge they have got in the previous courses. On the other hand, some other students stated that they could easily follow the examples on the guidelines and reference books. Besides, their basic knowledge of the tenses and conventions also influenced the correct way of quoting. It would make them easier to understand the change of tense in doing quoting that they could find the appropriate tenses and conventions for each subpart to convey information in the Introduction Part.

In brief, the analysis results of the questionnaire above show information of the students' abilities in writing the Introduction Part of a research report in English. It can be concluded that most of the students (more than 50\%) have several basic problems in writing a good and clear Introduction Part for their research report. The problems deal with the inability to use tenses and conventions properly, the incorrect way of quoting, the incorrect writing of research setting, and the inappropriate orientation of research writing. It could be restated that factors related to the previous knowledge and experiences were considered as the intervening factors that influenced writing a research report in English.

\section{CONCLUSION AND SugGeStion}

The sources of pr The sources of problems are basically emerging from the lack of knowledge and unfamiliarity with the five steps in writing the Introduction Part. Since writing is a productive skill, regular practice is required. The understanding of following the five steps and of setting a clear and reasonable research background can be acquired gradually when the students read much and practice a lot. The understanding cannot be separated from the availability of supporting references related to academic wiriting. The problems on the use of tenses can be viewed from the students' inability to understand English grammar as it becomes so structurized in making the statements based on the time lapses. The ability of quoting may be improved if the students understand and refer to the rules of making quotations based on their reference books and guidelines. Since the way of communicating ideas can be different for each student, there is no strict style to be followed in writing, as long as it is still in the corridor of academic writing. The ability to differentiate the use of words, dictions, and the 
effectiveness of the sentences written is a need for the target readers to understand.

Viewing that writing a good research report in English is very crucial for academic purposes, findings in the research can be a reflection for the education practitioners to put more serious consideration towards the problems. The results may give a basic decision to make more sophisticated research writing report guidelines. For the lecturers, the problems may become the targets of improving the teaching objectives, for example, by directing the activities in academic writing course to analyze the Intoduction Part of research reports, to practice the tenses used in the Introduction Part, and to make restatements or citations, to paraphrase, or to summarize the provided quotations. In other words, familiarity with research report writing, that is, the use of tenses and conventions, as well as much practice in writing and reading more would be a great help to avoid further difficulties.

The research has a very limited source of data on the student's perceptions or opinions dealing with the five stages in writing the Introduction Part of a research report in English; therefore, further analyses are still needed to give more reliable results.

\section{REFERENCES}

[1] D. B. Taylor, A Guide To Verb Tense Voice and Mood In Scientific Writing. University of Toronto. (Online), 2007, retrieved on March 18,
2017

from /index.php/hswriting/article/download/3340/1476

[2] Fachrurrazy, Teaching English as a Foreign Language for Teachers in Indonesia. Malang: State University of Malang Press, 2012.

[3] J. Hartley, Academic Writing and Publishing: A practical handbook. New York: Roudledge, 2008.

[4] A. A. Glathorn, and R. L. Joyner, Writing the Winning Thesis or Dissertation. Thousand Oaks, California: Corwin Press, 1996.

[5] C. B. Norris, Academic Writing in English. Helsinki: University of Helsinki. (Online), 2016, retrieved March 18, 2017 from www.helsinki.fi/kksc/language. services/AcadWrit.pdf

[6] R. Weissberg, and S. Buker, Writing Up Research. Experimental Research Report Writing for Students of English Englewood Cliffs: Prentice Custom Publishing/Pearson Prentice Hall, 2006.

[7] R. Weissberg, and S. Buker, Writing Up Research. Experimental Research Report Writing for Students of English. (Online), 2014, retrieved November 23, 2014 from http:www.uefap.com /materials/language-convention/language-conventions. Html

[8] B. Dwiloka, and R. Riana, Teknik Menulis Karya Ilmiah. Jakarta: PT Rineka Cipta, 2005.

[9] E. Emilia, Menulis Tesis dan Disertasi. Bandung: Alfabeta, 2008.

[10] A. Schuhart, "Teaching scientific writing in the two-year college. inquiry," The Journal of the Virginia Community Colleges, 19 (1), (Online), 2014, pp.15-39, retrieved March 18, 2017 from commons.vccs.edu/inquiry/vol19/iss1/3/

[11] S. M. Griffies, W. A. Perrie, and G. Hull, Elements of Style for Writing Scientific Journal Articles. Elsevier: Publishing Connect. (Online), 2013, retrieved March 18, 2017 from https://www. elsevier.com

[12] M. B. Miles, and A. M. Huberman, Qualitative Data Analysis: Second Edition. California: SAGE Publication, Inc, 1994. 